\title{
Nursing attrition and the work environment in South African health facilities
}

\author{
EJ Hall, MA, Employment and Economic Policy Research, Human Sciences \\ Research Council
}

\section{Abstract}

A number of media reports appeared on the shortages of professional health workers in the public health sector. Unsatisfactory working conditions in health facilities were mentioned as one of the key aspects responsible for the shortages. Literature indicates that stress caused by unsatisfactory work environments may play a major role in employees' decision to resign their jobs, in spite of enjoying the nature of their work.

The aim of this article is to explore the current human resource situation in nursing i.e. to determine if a shortage of nursing skills exists, to establish the challenges that nurses have to face in performing their duties and to establish the potential effect of the work environment on attrition.

Currently 155484 nurses are practicing in South Africa at a rate of 343 nurses per 100000 of the population, which compares favourably with the World Health Organisation minimum of 200:100000. The lack of reliable data on the supply of and demand for nurses makes it difficult to determine whether real shortages exist. However the supply of nursing services is influenced by the uneven distribution of skills across regions and the outflow of professional skills. It seems that the existing situation will deteriorate because fewer people are inter- ested in taking up or pursuing nursing as a career in South Africa. At the same time a need for more nurses was identified because of the growth in the population as well as a change in health care needs.

Workplace conditions for health workers employed at hospitals and clinics in South Africa were explored as part of a recent national study on the impact of HIV/ Aids on the health sector. Health workers' opinions on aspects such as workload, staff morale and working hours were obtained during personal interviews, which were conducted at $\mathbf{2 2 2}$ health facilities. Nine hundred and twenty four professional nurses, enrolled nurses and nursing assistants, who were mostly employed in the public health sector, participated.

A stressful work environment was identified in public hospitals and clinics. An increase in the number of patients visiting these facilities, accompanied by a lack of equipment, unsatisfactory work environment and a shortage of nurses were pointed out. Many patients cannot be accommodated elsewhere because of a lack of finance and alternative health care options. Nurses also indicated that they do not get much support from their employers. The effect of all these factors culminates in a stressed workforce who may be forced to consider alternative career options. This will be to the detriment of health care in the country.

\section{Opsomming}

Tekorte aan gesondheidswerkers en die rol wat onbevredigende werksomstandighede in staatshospitale daarin speel, was die onderwerp van verskeie mediaberigte wat onlangs verskyn het. Bestaande navorsing toon aan dat spanning wat voortspruit uit werksomstandighede, werkers mag oorreed om te bedank, selfs al geniet hulle die aard van hulle werk.

Teen hierdie agtergrond poog die artikel om te bepaal of daar " $n$ tekort aan verpleegsters bestaan, wat die uitdagings is waarmee verpleegsters in hulle werksituasie gekonfronteer word asook die moontlike invloed wat werksomstandighede op die omset van verpleegters mag hê.

Daar is tans 155484 praktiserende verpleegsters in SuidAfrika of 343 verpleegsters vir elke 100000 van die bevolking. Hierdie verhouding vergelyk goed met die Wêreld Gesondheid Organisasie se minimum aanbevole verhouding van 200:100000. Die bepaling van die werklike situasie word bemoeilik weens ' $n$ gebrek aan betroubare inligting oor vraag en aanbod. Huidige voorsiening word egter beïnvloed deur die oneweredige verspreiding van vaardighede tussen provinsies en 'n uitvloei van vaardighede uit die professie en die land.

Dit wil voorkom of daar ' $n$ afname in verpleegstergetalle is vanweë Suid-Afrikaners se gebrek aan belangstelling in verpleging as ' $n$ loopbaan. Terselfdertyd word ' $n$ behoefte aan meer vaardighede in die toekoms voorsien weens bevolkingsgroei en ' $n$ verandering in die gesondheidsorg behoeftes van Suid-Afrikaners.

Die werksomstandighede van gesondheidswerkers verbonde aan hospitale en klinieke in die land is onlangs ondersoek as deel van 'n studie oor die invloed van MIV/ Vigs op die gesondheidsektor. Tydens hierdie studie is persoonlike onderhoude met 924 professionele verpleegsters, stafverpleegsters en verplegingsassistente 
verbonde aan 222 hospitale en klinieke gevoer om hulle menings oor aspekte soos werkslading, moraal en werksure te bepaal. Die werksomgewing in staatshospitale en klinieke is spanningsvol vanweë ' $n$ toename in die aantal pasiënte, "n swak toegeruste werksomgewing en 'n tekort aan verpleegsters. Die situasie word vererger as gevolg van baie pasiënte se power finansiële situasie en die gebrek aan ander gesondheidsorg moontlikhede. Ten spyte van hierdie stuasie kry verpleegsters min ondersteuning van hulle werkgewers.

Hierdie faktore bring verhoogde stres onder verpleegsters mee wat hulle mag dwing om ander beroepsmoontlikhede te oorweeg, wat die kwaliteit en beskikbaarheid van gesondheidsorg kan benadeel.

\section{Introduction and aim}

"Florence Nightingale's lamp went out long ago." This alarming allegation was recently made in a media report on the insensitive behaviour of health workers towards patients at a public health institution (Greyling, 2003:8). Various reports have also appeared in recent times on the shortages of professional health workers in the public health sector (Swanepoel, 2002:11), the loss of medical practitioners and nurses to foreign countries

(Swanepoel, 2001a:9); Retief, 2001:21), and the shocking conditions in public health facilities (Swanepoel, 2001b:9). In most of these reports, the shortage of health professionals was linked to an increase in emigration. The working conditions in health facilities were also mentioned as one of the key aspects responsible for the apparent exodus of health workers.

Issues relating to health often evoke emotional responses without there being real evidence or hard facts to support claims. In this article, the author intends to explore the current human resource situation in nursing and to determine if a shortage of nurses really exists, as well as establishing what challenges nurses face in performing their duties. The potential effect of the work environment on attrition will also be addressed.

\section{Nursing resources in South Africa}

\section{Current supply of professional nurses}

The number of nurses ${ }^{1}$ practicing in South Africa is estimated at 155484 by the Labour Force Survey (LFS) of September 2001 (Statistics South Africa, 2002). Using the pro- jected South African population figures for 2001 (45 349 460, according to Van Aardt, Van Tonder \& Sadie, 1999:3), this gives a nurse:population ratio of $343: 100(0) 0$, which compares favourably with the World Health Organization (WHO) minimum of 200:100000)(WHO, 2002).

While it is difficult to determine whether or not shortages exist because of a lack of reliable data on the supply of and demand for nurses, shortages are more likely to be found in rural areas, with imbalances showing in regional and provincial figures. Although the overall provincial nurse:population ratio compares favourably to the WHO's minimum norm of 200:100000, provinces with large rural areas (such as the Northern Cape, Mpumalanga, Limpopo and Eastern Cape) have a ratio below the current average for South Africa (see Table 1).

As the demand for nurses in South Africa is escalating, and as the output of newly qualified nurses is the major source of future growth in the profession, it is therefore of great concern that there has been an average decrease in the total number of enrolments for nursing courses $(1,2 \%)$, as well as in the number of new entrants into the field $(0,9 \%)$ for the period 1990 to 2000 (see Tables 2 and 3).

\section{Factors affecting the demand for nurses}

Several factors affect the demand for nurses. Some of these relate to the replacement of nurses. For example, nearly a 


\begin{tabular}{|c|c|c|c|c|c|c|c|c|c|c|c|c|}
\hline $\begin{array}{l}\text { Institution/Type of } \\
\text { qualification }\end{array}$ & $\begin{array}{l}1990 \\
N\end{array}$ & $\begin{array}{l}1991 \\
N\end{array}$ & $\begin{array}{l}1992 \\
N\end{array}$ & $\begin{array}{l}1993 \\
N\end{array}$ & $\begin{array}{l}1994 \\
N\end{array}$ & $\begin{array}{l}1995 \\
N\end{array}$ & $\begin{array}{l}1996 \\
N\end{array}$ & $\begin{array}{l}1997 \\
N\end{array}$ & $\begin{array}{l}1998 \\
N\end{array}$ & $\begin{array}{l}1999 \\
N\end{array}$ & $\begin{array}{l}2000 \\
N\end{array}$ & $\begin{array}{c}\text { Average annual } \\
\text { growth per type of } \\
\text { qualification } \\
1990-2000 \\
\%\end{array}$ \\
\hline $\begin{array}{l}\text { Universities } \\
\text { (degrees and } \\
\text { diplomas) }\end{array}$ & 1640 & 1648 & 1796 & 2011 & 1953 & 1631 & 1760 & 1750 & 1842 & 1966 & 21.54 & 2.8 \\
\hline $\begin{array}{l}\text { Nursing Colleges } \\
\text { (diplomas) }\end{array}$ & 9716 & 10017 & 10046 & 10331 & 9664 & 9551 & 10403 & 10101 & 9445 & 8430 & 7485 & -2.6 \\
\hline $\begin{array}{l}\text { Enrolled nurse and } \\
\text { enrolled midwifes' } \\
\text { courses }\end{array}$ & 3612 & 3431 & 3597 & 3103 & 2093 & 1772 & 2470 & 3438 & 4144 & 3726 & 3811 & 0.5 \\
\hline $\begin{array}{l}\text { Nursing Auxiliary } \\
\text { courses }\end{array}$ & 2859 & 2782 & 2503 & 2129 & 2241 & 1772 & 2555 & 2053 & 1492 & 1536 & 2345 & -2.0 \\
\hline TOTAL & 17827 & 17878 & 17942 & 17574 & 15951 & 14726 & 17188 & 17342 & 16923 & 15658 & 15795 & -1.2 \\
\hline
\end{tabular}

Source: SANC, 2003.

* Excluding those qualifying from bridging courses.

\# Excluding enrolments from nursing schools due to gaps in the data and small numbers.

\section{Table 3: Nursing output from different courses, 1990 - 2000*\#}

\begin{tabular}{|c|c|c|c|c|c|c|c|c|c|c|c|c|}
\hline $\begin{array}{l}\text { Institution/Type of } \\
\text { qualification }\end{array}$ & $\begin{array}{l}1990 \\
N\end{array}$ & $\begin{array}{l}1991 \\
N\end{array}$ & $\begin{array}{l}1992 \\
N\end{array}$ & $\begin{array}{l}1993 \\
N\end{array}$ & $\begin{array}{l}1994 \\
N\end{array}$ & $\begin{array}{l}1995 \\
N\end{array}$ & $\begin{array}{l}1996 \\
N\end{array}$ & $\begin{array}{l}1997 \\
N\end{array}$ & $\begin{array}{l}1998 \\
N\end{array}$ & $\begin{array}{l}1999 \\
N\end{array}$ & $\begin{array}{l}2000 \\
N\end{array}$ & $\begin{array}{l}\text { Average annual } \\
\text { growth per type of } \\
\text { qualification } \\
1990 \text { to } 2000 \\
\%\end{array}$ \\
\hline $\begin{array}{l}\text { Universities } \\
\text { (degrees and } \\
\text { diplomas) }\end{array}$ & 258 & 346 & 351 & 293 & 336 & 328 & 355 & 377 & 363 & 333 & 269 & 0.4 \\
\hline $\begin{array}{l}\text { Nursing Colleges } \\
\text { (diplomas) }\end{array}$ & 1401 & 1770 & 2053 & 1682 & 2034 & 1876 & 2274 & 2305 & 2008 & 1930 & 2225 & 4.7 \\
\hline $\begin{array}{l}\text { Enrolled nurse and } \\
\text { enrolled midwifes' } \\
\text { courses }\end{array}$ & 2182 & 1565 & 1772 & 1661 & 1747 & 1269 & 1285 & 1361 & 1834 & 2629 & 1919 & -1.3 \\
\hline $\begin{array}{l}\text { Nursing Auxiliary } \\
\text { courses }\end{array}$ & 2658 & 1741 & 2311 & 1812 & 1705 & 1924 & 1426 & 2186 & 1567 & 1218 & 1510 & -5.5 \\
\hline TOTAL & 6499 & 5422 & 6487 & 5448 & 5822 & 5397 & 5340 & 6229 & 5772 & 6110 & 5923 & -0.9 \\
\hline
\end{tabular}

Source: SANC, 2003

* Excluding those qualifying from bridging courses.

\# Excluding outputs from nursing schools due to gaps in the data and small numbers. 


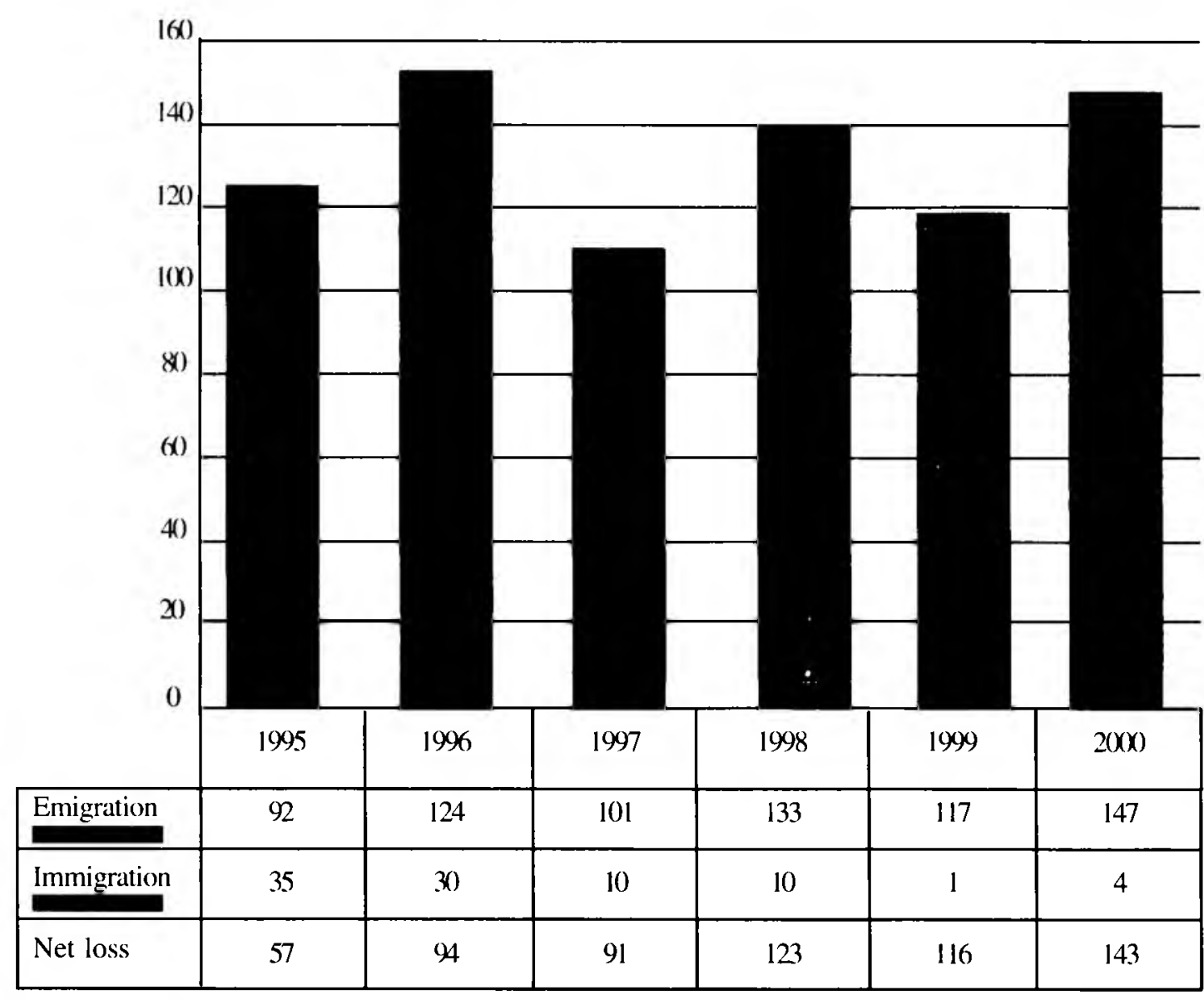

going to experience a negative growth rate because of HIV/ AIDS, this is not actually the case. According to Van Aardt et al (1999:4) the population will continue to grow, but at a slower rate than initially projected. Rehle and Shisana (2003:4) predicted that by 2020 the South African population would be $23 \%$ smaller than what it would have been without HIV/AIDS, yet they do not expect a negative population growth rate. One of the factors contributing to growth is the change in the health system, with large sections of the population who never had access to health care before, now entitled

fifth (34 965 or $18,4 \%$ ) of nurses on the SANC register no longer appear to practise their profession. The number of inactive nurses was calculated by subtracting the total number of employed nurses on the LFS ( 155484 ) for 2001 from the total number of nurses on the register ( 190449$)$ for the same year. This figure correlates with a 1990 study by Pim Goldby management consultants (cited by Brannigan, 2000:45), which estimated the non-active component in nursing at $19 \%$.

South Africa has also lost a number of nurses to other countries, although the exact figures are not known. The official migration statistics of nurses from 1995 to 2000 revealed an increase in annual net losses (see Figure 1). However, emigration figures for nurses are probably higher than officially recorded. For example, Brown, Kaplan \& Meyer (2002: 102) compared data from the five major recipient countries of South African emigrants with local information, and came to the conclusion that only $35 \%$ of emigrants were being captured by official data-collection methods. Nurses that left the country temporarily to practice their professions outside South Africa were also not included in the numbers in Figure 1.

Nurses who will die of HIV/AIDS will also need to be replaced. While there is still uncertainty among the experts on the exact extent of the HIV/AIDS epidemic in South Africa, the ING Barings study (2000:7) estimated that HIV prevalence rates would peak at $13,1 \%$ for highly skilled and at $22,8 \%$ for skilled categories of the labour force.

There are indications that more nurses will be needed in future. Although the popular view is that South Africa is to receive health services free of charge.

What is more, the increase in the incidence of communicable human diseases such as HIV, cholera and tuberculosis (TB) means that additional nurses are going to be needed to attend to the health needs of the infected. According to Girdler-Brown (2001:43), the incidence of TB has shown an annual increase of 5-10\% over the past decade, while the most recent outbreak of cholera in KwaZulu-Natal appeared to be the largest and most serious one to date. At the same time, the rate of HIV infection continues to increase and HIV prevalence in the labour force is projected by some analysts to peak only in 2006 (Bureau for Economic Research, 2000:3).

\section{Work environment, attrition and retention of employees} General factors

Studies conducted outside the field of health often draw links between work context and the attrition or retention of employees. In investigating the rate at which waste collectors and municipal workers left their jobs, Lund, Iversen and Poulsen (2001:167) found that physical and psychosocial work environment factors were the most common factors affecting people's decisions to their jobs.

Billingsley (1993:146) reviewed the literature on teacher retention and attrition in special and general education, and 


\begin{tabular}{|l|l|l|}
\hline Total (N=924) & Total (\%) & CI 95\%5 \\
\hline Gender & & \\
Male & 6.4 & $(4.5,9.2)$ \\
Female & 93.0 & $(90.7,94.8)$ \\
\hline Race & & \\
African & 69.6 & $(55.8,80.6)$ \\
Coloured & 11.0 & $(6.7,17.5)$ \\
Indian & 4.8 & $(1.7,12.8)$ \\
White & 14.1 & $(7.2,25.8)$ \\
Other & 0.4 & $(0.2,1.2)$ \\
\hline Age & & \\
30 years and younger & 15.7 & $(11.2,21.7)$ \\
$31-40$ years & 37.8 & $(33.2,42.6)$ \\
$41-50$ years & 32.8 & $(26.7,39.5)$ \\
51 years and older & 13.5 & $(10.0,18.1)$ \\
Unknown & 0.2 & $(0.0,1.1)$ \\
\hline Highest qualification & & \\
First degree/ higher diploma and higher & 17.8 & $(12.8,24.1)$ \\
Diploma/ Occupational certificate & 62.1 & $(53.5,70.1)$ \\
Grade 12 & 12.8 & $(8.2,19.4)$ \\
Grade 10-1 I & 5.8 & $(3.9,8.6)$ \\
Lower than Grade 10 & 1.5 & $(0.5,4.0)$ \\
\hline
\end{tabular}

physical and emotional strain.

Similar studies were conducted in the field of health work. One such study of nursing staff retention identified dissatisfaction with the work environment and job-related stress/anxiety as two major reasons for turnover (Clark, Clark, Day \& Shea, 2000:92-96). Brown, Schultz, Forsberg, King, Kocik \& Butler (2002:48-54) reported on predictors of retention among health care professionals working with patients with chronic illnesses such as HIV. Retention of nurses was significantly associated with initial job satisfaction, being married and low levels of stress. In a survey to determine factors possibly associated with poor recruitment and failure to retain nurses and therapists working with stroke patients, the North Central London Workforce Development Confederation found that occupational stress played an important role in the turnover of nurses (Webb, 2002:36-37). Burnout among nursing staff, caused by a "toxic health care environment ${ }^{2}$ " has also been found to contribute to employee attrition in nursing (Cullen, 1995: 23). However, the decision to remain in a job is not necessarily directly linked to job satisfaction. For example, Brown, Schultz et al (2002:48-54) established that job satisfaction was not a reliable predictor of a person's intention to remain in a job, while Landman, Mouton \& Nevhutalu (2001: 60) found that although hospital staff were "generally satisfied with their jobs and found [them] interesting and stimulating", $40 \%$ of staff frequently thought about leaving their jobs.

In summary, it appears that stress caused by challenging conditions in the work environment - such as work overload, lack of support, staff shortages, inadequately equipped work environments and the absence of proper incentives -

came to the conclusion that work conditions and rewards were consistently associated with teacher retention. For example, it was found that unsupportive work environments and problems with role expectations could increase stress, burnout and eventual attrition among educators, while collegial interaction and support were linked with satisfaction and retention. Problems associated with job overload were also linked to attrition.

Emotional exhaustion, caused by too much work and continuous pressure in the work environment, also contributes to attrition. Wright and Cropanzano (1998:492) looked at emotional exhaustion as a predictor of job performance and voluntary turnover. They discovered that emotionally exhausted workers eventually left their jobs as a result of declining job performance brought on by long periods of may persuade nursing employees to leave their jobs even if they enjoy the nature of their work.

\section{Factors affecting nurses at health facilities in South Africa}

Stressful working conditions in the South African public health system were reported in an investigation by TURP (2001:1-7) into the reasons for emigration by South African nurses. Although the number of responses was limited, the results of the investigation nevertheless showed that aspects such as a lack of competitive incentives, work pressure, lack of opportunities for promotion and inadequately resourced working environments led to the loss of profes-

2. Cullen (1995:23) uses this term to refer to "the pressure that's put on to nurses by external organisational forces that determine the conditions under which they work".

3 Health workers were questioned on work-related issues that could be affected by the prevalence of HIV/AIDS, without reference being made to the disease.

4 Weighted percentages. Percentages may not add up to 100 owing to rounding.

5 Confidence interval (95\%). 
sional nursing skills.

A study conducted by the Ethics Institute of South Africa (Landman et al, 2001:1-167) at the Chris Hani Baragwanath Hospital showed that most staff members found their work environment unacceptable and unsafe. Their opinions were based on factors such as neglect, poor maintenance of buildings and insufficient and outdated equipment. The majority also expressed dissatisfaction with their workload, salaries and the problem of staff shortages.

Workplace conditions for health workers employed at hospitals and clinics across the nine provinces of South Africa were explored as part of a recent study on the impact of HIV/AIDS on health workers (Shisana. Hall, Maluleke, Stoker, Schwabe, Colvin, Chauveau, Botha, Gumede, Fomundam Shaikh. Rehle, Udjo \& Grisselquist, 2002). Health workers' opinions ${ }^{3}$ on aspects such as workload, staff morale and working hours were obtained during personal interviews, which were conducted at 222 health facilities representative of the public and private health sector in South Africa. The sample was designed to provide nationwide representation of professional and non-professional health workers. However, for the purpose of this article only the responses of nurses were considered. Nine hundred and twenty four professional nurses, enrolled nurses and nursing assistants participated (see profile in Table 4). Most of the respondents $(84,3 \%)$ were employed in the public health sector.

The majority of nurses $(79,2 \%)$ who participated in the study said that they had experienced an increased workload during the past year. Of these, $49 \%$ indicated an increase in their workload of between $50 \%$ and $75 \%$, while nearly a fifth felt that their workload had doubled. One third of participating nurses $(33,6 \%)$ stated that they often worked longer than their official working hours, providing further evidence of heavy workloads. They mainly attributed this situation to staff shortages and a higher patient load, as well as increases in numbers of patients with HIV-related diseases. As a result, they experienced increased stress, physical exhaustion, dissatisfaction and a lack of motivation.

Less than half $(48,8 \%)$ indicated that support from their employers (such as counselling) was available to them if and when they needed it. In a number of cases, what support was available had to be paid for from the nurses' medical funds.

Respondents also believed that the increase in patients who take longer to recover, impacted negatively on the quality of their work. Although the emphasis should be on holistic health care, nurses at public clinics said that they could barely find the time and the resources (medication, for example) to attend to the physical needs of the daily turnout of patients, let alone provide quality care. Other responsibilities, such as administration and record-keeping, have to be dealt with after hours.

Absenteeism has increased due to stressful working conditions, which has made the burden even heavier on those members of staff who report for work. Not surprisingly, $16,2 \%$ indicated that they had been treated for stress or stress-related illnesses in the year prior to the survey.

Study results indicated further that the prevalence of HIV/
AIDS has had a major impact on nurses, as well as on their jobs as health caregivers. Nearly half $(46,4 \%)$ were afraid that they might infect their partners or children because of their exposure at work to HIV/AIDS-infected patients; and $16,2 \%$ indicated that they would consider leaving their current jobs if they believed the risk of contracting the disease in their workplace would escalate. Furthermore, $65,8 \%$ of nurses pointed out that the fact that HIV/AIDS is not a notifiable condition posed challenges to them in caring for their patients. These challenges were not only linked to fear of infection, but were also caused by the cultural, social and educational background of patients, as well as their lack of money. For example, the stigma attached to the disease led to many HIV sufferers being rejected and isolated by families and friends. As a result, nurses had to take care of aspects relating to patient care other than their medical needs.

Most of the people living with HIV/AIDS (PLWA) could not afford alternative (private) care and were dependent on subsidised health care. Due to a shortage of supplementary care such as facilities (such as hospices) and volunteers to assist, public health facilities were overcrowded with HIV cases. This situation has had a negative impact on the workload and emotional wellbeing of nurses in public health facilities. On top of the heavy workloads, no cure or healing could be offered to the majority of their patients - a fact that depressed people who generally regarded themselves as healers. Another factor that upset nurses was that patients with treatable non-HIV-related conditions could not always be accommodated in hospitals due to overcrowding.

The unsatisfactory work situation of nurses was further illustrated by the fact that only $40,9 \%$ nurses who participated in the study believed that staff morale was high in the health facilities where they were employed. These nurses linked satisfactory working conditions, as well as factors such as the ability to provide high-quality health care, low absenteeism and adequate remuneration, to high morale. Low morale, on the other hand, was associated with a stressful work environment characterised by heavy workloads, low salaries, staff shortages, a lack of managerial support and unhappy and frustrated colleagues.

In spite of the challenges encountered in their work environment, the majority of nurses $(81,3 \%)$ enjoyed their work and experienced job satisfaction. It is clear from their comments that their contentment results from putting their profession as health care givers into practice, rather than their specific working conditions. Nevertheless, nurses who lacked job satisfaction explained this in terms of heavy workloads, stressful conditions, staff shortages, the lack of time for quality care and low salaries.

The study confirmed that a stressful work environment often existed in hospitals and clinics in the health sector. particularly in the public health sector. An increase in the number of patients visiting these facilities, poorly equipped work environments and a shortage of nurses were identified as stressors. The situation was aggravated by the fact that many of patients could not be accommodated elsewhere because of a lack of finance and alternative health care options. By and large, PLWA took longer to recover from illnesses, and nursing staff generally spent more time 
and energy on these patients due to the seriousness of their condition and the lack of support they received from their families and friends. Nurses also indicated that they generally did not receive much support from their employers, in spite of their difficult working circumstances.

These factors have culminated in a stressed and exhausted workforce who in many cases no longer believes that they can provide quality health care. While nurses may still be satisfied with the content and nature of their jobs as health care providers, many of them felt powerless and on the verge of burnout in their current job situation.

\section{Concluding remarks Decreases in the supply of nurses}

Nursing enrolments and outputs from institutions of higher education show a decline for the period 1990 to 2000$)$. South Africa is also losing an increasing number of nurses to other countries, as well as to mortality as a result of HIV/ AIDS. At the same time, the need for nurses is expected to increase because of the growth in the population, the system of free health care and an expected increase in the incidence of communicable diseases.

More people need to be recruited and trained in order to ease the workload of nurses in the public health sector. Recruitment could start with registered nurses who no longer practise their profession. Incentives such as refresher courses and acknowledgement of past experience should be offered when persuading these professionals to return to nursing.

At the same time training institutions should try to increase nursing output by ensuring that more candidates complete their studies successfully. According to Brannigan (2000:45), the normal dropout rate over the four-year training period for registered nurses is $20 \%$. Although more comprehensive data on the number of nurses who fail to complete their training could not be obtained, a comparison of the enrolment and output figures indicates that many nursing students do not complete their training. If more of these candidates could finish their studies, the supply of nurses would increase. In an effort to address this situation, it is recommended that more details on students (such as profile, progress after enrolment, reasons for failure) and student support services (such as career counselling) should be collected from training institutions.

As the nursing profession competes with other serviceoriented occupations in terms of recruiting new applicants and retaining existing skills, the salary and benefit packages of nursing staff should be addressed. Traditionally, career decisions were influenced by a sense of vocation towards a specific occupation, while job opportunities for women were limited to a few occupational areas, the most obvious being nursing and teaching. These days, women have a wide range of career options to choose from. Their decisions are influenced by various factors, including incentives, work environment, opportunities for further development and family commitments. Employment equity legislation also encourages employers to appoint more women. If one assumes that the inactive nurses on the SANC register are employed elsewhere, it seems that nurses have a combination of skills that they can successfully apply in other occupations.

The profession should be promoted through a marketing process that will stimulate the interest of young people by focusing not only on job content, but also on the possibilities and benefits attached to nursing. For example, apart from job related information, the possibilities for career development, opportunities to combine a career in nursing with a family, as well as the opportunity to earn an income while studying, should be pointed out when information on a career in nursing is compiled. It should be kept in mind that practicing nurses also play an important role in the marketing (both negative and positive) of their profession. Although they may remain in nursing because of factors such as the lack of available alternative employment, they may discourage prospective new entrants from joining. Improvements in the work environment and working conditions of nurses are therefore vital not only in attracting new interest to the profession, but also to encourage the current pool of skills to remain in nursing.

\section{Stressful work environment}

The work environment of nurses employed at health facilities operating in the public health sector, is stressful and unsupportive. As a result, many nurses believe they are no longer able to provide proper health care. This is mainly due to factors over which they have no control, such as staff shortages, an increase in the number of patients and the prevalence of HIV/AIDS. These factors may force nurses to consider alternative career options, such as practising their profession elsewhere or moving out of nursing.

The outflow of nursing staff and the lack of interest shown in the profession will not turn around unless improvements occur in the workplace. Hospitals and clinics should be equipped with the necessary infrastructure and logistics to increase health workers' performance and their job satisfaction In the current work environment, where a limited number of nurses have to provide health services to increasing numbers of patients, the facilities should contain sufficient resources (including equipment, medicine and support such as management information systems) to enable nurses to operate effectively.

Employers should also support staff by offering stress management programmes and counselling services to help them to cope with stress in their work environment. Such services should be free of charge and accessible to all levels of staff. Nurses should be encouraged to seek help, while employers need to reject the old-fashioned but persistent belief that nurses who find it hard to cope do not belong in the nursing profession.

\section{Uneven distribution of skills across regions}

According to the World Health Organization minimum requirements, South Africa does not have a shortage of nurses. There is, however, a disproportionate distribution of nurses within the country, with below average numbers in those provinces with a large rural population.

The workload of nurses operating in rural areas is particu- 
larly affected because of the shortages of nurses as well as other health professionals in those areas. In many cases, nursing staff are forced to provide services outside the scope of their jobs or proficiency because of a lack of appropriate professionals (Pick et al, 2001:81). It is recommended that nurses should be provided with assistance in the areas of their work that do not require health-related skills (such as record-keeping and administration). In healthrelated areas, assistants with lower skills levels can be recruited and trained to perform routine tasks under professional supervision. Apart from easing the workload of health workers in rural areas, a uniform quality of health care can be provided by this approach. It will also have a positive impact on the creation of sustainable employment at lower skills levels. Furthermore, the burden of institutionalised care that is currently carried mostly by public health facilities could become more manageable if health caregivers and volunteers are recruited from the local communities. Such volunteers could help with home-based health care, including home or follow- up visits to the chronically ill, as well as providing health education and awareness campaigns under professional supervision.

\section{A lack of data on the supply of and demand for nurses}

The lack of reliable data on the supply of and demand for nurses should be addressed to ensure effective human resource planning over time. The SANC register is the most comprehensive source of data on nurses; however, no data is available from the register on the number of professionals currently actively employed in nursing in South Africa. It is also difficult to determine the number of first-time entries into the profession, as this information is mixed with data on those who upgrade their existing skills. Employment data on the private health sector is not available. To increase effective human resource planning, it is recommended that the register collect more detailed information on the current employment and qualification profiles of nurses.

\section{References}

BUREAU FOR ECONOMIC RESEARCH (South Africa) 2000: HIV/AIDS and the South African Economy. Economic Research Note No 8. Stellenbosch: Bureau for Economic Research.

BILLINGSLEY, BS 1993: Teacher retention and attribution in special and general education: A critical review of the literature. Journal of Special Education. 27(2): 137-174.

BRANNIGAN, E 2000: Macro Issues in Nursing. Health Annals. June 2000: 43-51.

BROWN, LK; SCHULTZ, JR; FORSBERG, AD; KING, G; KOCIK, SM \& BUTLER, RB; 2002: Predictors of retention among HIV/ hemophilia health care professionals. General Hospital Psychiatry. 24( 1): 48-54
BROWN, M; KAPLAN, D. \& MEYER, J. 2002: The Brain Drain: An Outline of Skilled Emigration from South Africa. (In Mc Donald, D.A.\& Crush, J. Eds. 2002: Destination Unknown: Perspectives on the Brain Drain in Southern Africa. Pretoria: Mc Printers, pp 99-112).

CCS (CENTRAL STATISTICAL SERVICES) 1998a: Tourism and Migration 1995. Report No. 03-51-01, Pretoria.

CCS (CENTRAL STATISTICALSERVICES) 1998b:Tourism and Migration 1996. Report No. 03-51-01, Pretoria.

CLARK, D; CLARK, P; DAY, D \& SHEA, D 2000: The relationship between health care reform and nurses' interest in union representation: The role of workplace climate. Journal of Professional Nursing. 16(2): 92-96.

CULLEN, A 1995: Burnout. Why do we blame the nurse? American Journal of Nursing. November 1995: 23-28.

GIRDLER-BROWN, BV 2001: Prevention and Control of Communicable Human Diseases. Health Annals. June 2001: $31-45$.

GREYLING, M 2003: Abattoir vir mense. Staatsdokters, verpleegsters is robotte wat eenhede prosesseer. NaweekBeeld. 22 Februarie: 8.

ING BARINGS, SOUTH AFRICAN RESEARCH 2000: Economic Impact of Aids in South Africa: A dark cloud on the horizon. Johannesburg.

\section{LANDMAN, WA; MOUTON,J \& NEVHUTALU, KH 2001:} Chris Hani Baragwanath Hospital. Ethics Audit. Ethics Institute of South Africa. Research report no 2. Accessed 19 September 2002 at <http://www.ethicsa.org/ report_chb.html.

LUND, T; IVERSEN, L \& POULSEN, KB 2001: Work environment factors, health lifestyle and marital status as predictors of job change and early retirement in physically heavy occupations. American Journal of Industrial Medicine. 40: 161-169.

PICK, W;NEVHUTALU,K; CORNWALL,JT \& MASUKU, M. 2001: Human Resources for Health. A National Strategy, Pretoria: Department of Health. (Report of the Human Resources in Health Task Team).

REHLE, TM \& SHISANA, O 2003: Epidemiological and demographic HIV/AIDS projections: South Africa. African Journal of AIDS Research. 2(1): 1-8.

RETIEF, H 2001: Die jong dokters en die Zuma-jaar: Hier in die boendoe maak ons ' $n$ verskil. Rapport. 21 April 2001:21.

SANC (SOUTH AFRICAN NURSING COUNCIL) 2003: SANC Register of Nursing Staff, Pretoria.

SHISANA, O; HALL,E; MALULEKE, KR;STOKER, DJ; SCHWABE, C; COLVIN, M; CHAUVEAU,J; BOTHA, C; 
GUMEDE, T; FOMUNDAM, H; SHAIKH, N; REHLE, T; UDJO, E. \& GRISSELQUIST, D. 2002: The impact of HIV/ AIDS on the health sector. National survey of health personnel, ambulatory and hospital patients and health facilities, 2002. Report prepared for the South African Department of Health. Pretoria: Human Sciences Research Council.

STATS SA 1999: Documented Migration 1997 and 1998 , Report No. ()3-51-(03, Pretoria.

STATS SA 2000: Documented Migration 1999, Report No. 03-51-03, Pretoria.

STATS SA 2000: Tourism and Migration 2000, Statistical release $\mathrm{P}(\mathbf{3 5}$ 1, Pretoria.

STATS SA 2001: Documented Migration 2(1)0, Report No. 03-51-03, Pretoria.

STATS SA 2002: Labour Force Survey, September 2001. Pretoria.

SWANEPOEL, T 2001a: Dokters nie verraaiers; verander net hul opleiding. Beeld. 3 April $2001: 9$.

SWANEPOEL, T 2001b: Waar lewe goedkoop is. Beeld. 3 April 2001:9.

SWANEPOEL, T 2002: Krisis om personeel "kan ons laml?", s? DG. Beeld. 29: Oktober 2002:11.

TURP(TRADEUNION RESEARCHPROJECT) 2(0)1:Understanding nurse emigration: Final report.

VAN AARDT, CJ; VAN TONDER, JL \& SADIE, JL 1999: A Projection of the South African Population, 1996-2021. Pretoria: Bureau of Market Research, Unisa.

WEBB, Y 2002: Nursing the nurses: why staff need support. Nursing Times. 98( 16): 36-37.

WHO(WORLD HEALTH ORGANISATION) 2002: WHO estimates of health personnel. <http://www3.who.int/ whosis/health_personnel/health_personnel.cfm $>$ Accessed 5 September.

WRIGHT, TA; CROPANZANO, R 1998: Emotional exhaustion as a predictor of job performance and voluntary turnover. Journal of Applied Psvchologv. 83(3): 486-493. 